\title{
Realising a Minimal State: The Case of Afghanistan
}

\author{
William Maley
}

I

$\mathrm{N}$ recent times a great deal of scholarly effort has been invested in tracing the contours of 'weak', 'failed', or 'collapsed' states such as Somalia, Mozambique, and Afghanistan. From the grim pictures of a realised Hobbesian state of nature which these discussions paint, a dose of 'state building' might seem exactly what these countries require to overcome their problems. Yet the obliteration of elements of the state may prove to be a silver lining in dark clouds. In particular, while Afghanistan's route to the minimal state passed through Hell, its prospects for recovering from nearly 18 years of savage conflict may be better than many commentators are prepared to concede.

\section{The Impact of Communism}

The Afghan state before the communist coup of April 1978 was weak, but ubiquitous and corrupt. It had developed into a 'rentier state' in which foreign aid and indirect taxes were used to fund a burgeoning bureaucracy. This had the effect of making the state, as one observer put it, 'independent of its citizens, urban or rural' (Shahrani, 1986:59). Statist policies produced a flow of university graduates who aspired to secure state employment and became increasingly alienated as the dryingup of foreign aid made such positions harder to obtain, at least on the basis of merit rather than connections.

The results of the 1978 coup are by now all too well known. The new communist regime attempted to enforce social transformation on a scale which far exceeded either the wishes of the population or the resources of the state, and met with almost immediate resistance. Fragmentation in the regime and a real risk that it would be overthrown triggered a full-scale invasion by the Soviet Union in December 1979. As a result, the Afghan state substantially disintegrated; its domestic revenue sources evaporated, and it depended significantly on Soviet subventions, together with inflation and sales of natural gas, to fund its core activities. With the cessation of Soviet aid from the beginning of 1992, the regime's crisis of legitimacy came to a head, and within four months it had collapsed. Since then, the country has been fragmented on geographical lines between different forces.

The scale of damage to the Afghan economy during the years of war was staggering. Agricultural output in 1986 stood at less than half of its 1978 level (SCA, 1988:4), and infrastructure was particularly targeted by Soviet forces: by 1993, approximately 60 per cent of Afghan schools had no buildings (UNO/ESSP Research

William Maley is Senior Lecturer in Politics, University College, The University of New South Wales, Canberra. 
and Planning, 1994, Vol.I:18). Over 2,300 minefields littered the countryside (MCPA, 1993, Vol.I:1). Transport networks, vital in expanding markets and economies of scale, were severely disrupted, and human capital formation was blocked by the displacement of millions of Afghan refugees (Maley, 1990).

Nonetheless, the Afghan economy has proved more robust than many might have expected, despite the sharp decline of Western interest in Afghanistan with the end of the Cold War. The collapse of the communist regime prompted the largest and fastest spontaneous repatriation of refugees in the history of the Office of the United Nations High Commissioner for Refugees, and this occurred without starvation resulting. Furthermore, much of the country has been a hive of reconstruction activity, belying the image of chaos and turmoil too often presented in the popular press (Maley \& Saikal, 1995). While it would be perilous to take too sanguine a view of Afghanistan's prospects - it remains one of the world's poorest countries, and performs lamentably when assessed according to standard indices of development such as infant mortality and adult literacy - a number of factors give grounds for guarded optimism.

\section{Grounds for Optimism}

First, the state has been reduced almost to the level of night watchman - as I discovered when assisted by the police after a puncture had left me in the streets during the hours of curfew in Kabul in May 1995. While strong enough to confront its armed opponents on the battlefield, it lacks the means to extract resources from its subjects for the personal benefit of the rulers. Furthermore, the collapse of the state has also fractured the rent-seeking coalitions of state officials and local notables which often made peasants' lives a misery and prompted them to seek the protection of benevolent local khans. This has created space for new approaches to economic activity in rural areas, notably the emergence of collectives of notables to manage the local implementation of reconstruction projects, at which a number have proved to be adept.

Second, the Afghan private sector has showı itself to be extraordinarily resilient. It has supplied means of transport for repatriating refugees; it feeds the bulk of the population; it has created most of the jobs. Agricultural activity in particular has revived surprisingly fast: seed quality has risen; fertiliser and farm power are more readily available; there have been increases both in yields and in area cultivated of traditional grain crops; and, in 1993, no fewer than 31 per cent of farmers surveyed by the SCA (1994:ii, v) had hired tractors to use in their work. Furthermore, a number of Afghan businessmen have recently returned to Kabul from Europe and America with highly developed commercial skills and a willingness to invest in the country's future. Visitors to Afghanistan are invariably struck by the vitality of small business, in which many returnees seek employment. While banking services of the traditional Western variety are nowhere to be found, and Afghan currency is printed under contract in Russia, there is a highly competitive foreign exchange market (located in a field in north Kabul) populated by traders clutching Afghan 
money who adjust their exchange rates to take account of variations in economic circumstances and the political climate.

One of the main reasons for the relatively successful revival of private initiative is that the Islamic faith, to which the overwhelming majority of Afghans adhere, continues to provide a framework of rules within which contracts are made. This in turn serves as a vital underpinning of the market order, which can exist only within a framework of rules establishing property rights and institutions of reciprocal obligation. Powerful social sanctions punish those who are dishonest in the commercial sphere, and the kind of criminality that has afflicted post-communist societies in Europe and even the secularised republics of Central Asia has not affected Afghanistan on anything like the same scale.

Third, Afghanistan has benefited from an infusion of skills associated with the involvement for more than a decade of non-governmental organisations (NGOs) in efforts to assist refugees in Pakistan, and to establish projects to sustain communities within Afghanistan. While there have been problems associated with the sudden arrival of NGO assistance, notably adverse effects in some cases on community cohesion and independence (Jawad, 1992; Leslie, 1995), the overall effects of NGOs have been distinctly positive. There is now a cohort of energetic Afghans who appreciate the expectations of both foreign aid donors and foreign business, and approach reconstruction tasks from an organic rather than mechanistic perspective, in stark contrast to some of the international agencies with which they come into contact. An offshoot of this development has been a proliferation of Afghan NGOs, and while a large number of these are no more than fly-by-night business firms, derisorily labelled 'briefcase NGOs' (Dupree, 1994:21) some have proved extremely effective.

This has led to the emergence of the Afghan 'Quango'. One of the grimmer elements of the present rulers' heritage has been a dispirited bureaucracy of riskaverse, rule-obsessed clerks whose interests stretch no further than the regular collection of their salaries. While the temptation to invite them to seek other employment must have been strong, the political costs of doing so could have been considerable. As a result, they have simply been bypassed, and new organisations, nominally private but operating with the blessings of the state and exploiting highlevel access to leading regime figures, have emerged to discharge what might ordinarily be regarded as state functions, such as care of the indigent. Notable among these are the Social Volunteers Association of Afghanistan and the Office for Administrative and Economical Development of Afghanistan. Whether this will prove more than a transient phenomenon is difficult to tell, but it offers a route by which to avoid some of the more exasperating attributes of Third World state administrations, such as a preoccupation with process rather than outcomes.

\section{Prospects}

Whether Afghanistan will be able to resist the temptation to press for a larger and more intrusive state remains problematical, because of pressures originating in the wider international system. The weakness of the state, together with opportunities 
for profit, have led Afghanistan to become one of the world's largest opium producers. This has exposed the Afghan government to significant, if maladroit, sanctions. In March 1995, the United States banned the supply of official nonhumanitarian aid to Afghanistan, on the grounds that the Afghan government had not taken 'adequate steps' to meet the goals of the 1988 UN Convention on Drug Trafficking. This was superficially true - but only because the Afghan government had been preoccupied for much of 1994 with rocket attacks on Kabul by an opponent identified in 1989 as the likely owner of the world's largest heroin factory, whose weaponry had been substantially funded by the US during the 1980s, and with whom as late as June 1995 the US ambassador to Pakistan contrived to meet.

Afghanistan's neighbours pose another problem. As a distinguished Afghan journalist remarked to me, while a minimal state may be ideal for economic reconstruction, it also facilitates attempts by Pakistan, Uzbekistan and Iran to seek to dominate Afghanistan in pursuit of their own ideological, economic and security interests. The fall of the city of Herat, a model of laissez-faire reconstruction, to a Pakistan-backed coalition of theology students in September 1995 unfortunately showed this to be a real danger (Maley, 1995). Ultimately it is politics, not economics, which poses the greatest obstacle to realising the minimal state.

\section{References}

Dupree, N. (1994), 'Afghan Initiatives', Refugees 3: 20-1.

Jawad, N. (1992), Afghamistan: A Nation of Minonities, Minority Rights Group, London.

Leslie, J. (1995), 'Towards Rehabilitation: Building Trust in Afghanistan', Disaster Prevention and Manıagement 4(1): 27-31.

Maley, W. (1990), 'Afghan Refugees: From Diaspora to Repattiation', pp.17-44 in A. Saikal (ed.), Refugees in the Modenn World, Department of International Relations, Research School of Pacific Studies, Australian National University, Canberra.

— (1995), 'Afghan plan pure folly for Pakistan', The Canberra Times, 11 September.

_ \& F. H. Saikal (1995), 'Post-Communist Afghanistan: Myths and Realities', Quadrant 39(5): 5964.

Mine Clearance Plaming Agency (MCPA) (1993), Report of the National Survey of Mines Situation, Peshawar, Vols.I-II.

Shahrani, M. (1986), 'State Building and Social Fragmentation in Afglanistan: A Historical Perspective', pp.23-74 in A. Banuazizi \& M. Weiner (eds), The State, Religion, and Ethnic Politics: Afghamistan, Iran, and Pakistan, Syracuse University Press, Syracuse.

Swedish Committee for Afghanistan (SCA) (1988), The Agricultural Survey of Adghamistan: First Report, Peshawar.

— (1994), The Agzicultural Survey of Afghauistun: Nineteenth Report, Peshawar.

UNO/ESSP Research and Planning (1994), The Status of Education in Afghanistan, Peshawar, Vols. I-II. 